\title{
WWII MONUMENTS IN YUGOSLAVIA IN THE PRINTED MEDIA: BOOKS, TOURIST GUIDES AND A STICKER ALBUM - POPULARIZATION AND PROPAGANDA
}

UDC 316.774:725.945(497.1)

\begin{abstract}
Nenad Lajbenšperger
Institute for the Protection of Cultural Monuments of Serbia, Belgrade, Serbia

Abstract. Publications about monuments to fighters and victims of the Second World War in Yugoslavia began to appear in the late 1950s. They were dedicated to one or more monuments or memorial complexes. Over time, in tourist guides, among other sites, monuments and memorials began to be presented as a significant place worth a visit. During the second half of the 1970s, printing of special tourist guides dedicated only to monuments and memorial complexes started. Because of the popularity of monuments, a sticker album was also printed. The intention behind printing such publications was to inform citizens about monuments, but there was also an ideological side to it. Through books about monuments, the state and the Communist party wanted to emphasize again Yugoslav war efforts and the sacrifice that was made during the war. They used it as a propaganda tool in youth education, foreign diplomacy and overall state propaganda about the role of Yugoslav partisans, under the leadership of the Communist party, in the victory against fascism.
\end{abstract}

Key words: monuments, memorials, publications, books, tourist guides, sticker album, People's Liberation War in Yugoslavia.

\section{INTRODUCTION}

Monuments to the partisans who died for the liberation of Yugoslavia from the occupiers began to be built while the war was still going on. With the end of the war, more intense building of monuments began. In the beginning, they were mostly in the shape of the memorial plaques and monuments of a simpler form, or in the style of social realism. With the raise of the country's economy during the 1950s, erecting more monumental monuments and

Received July 23, 2020 / Accepted October 13, 2020

Corresponding author: Nenad Lajbenšperger

Institute for the Protection of Cultural Monuments of Serbia, Radoslava Grujića 11, 11118 Belgrade, Serbia

E-mail: lajben@yahoo.com 
memorial complexes began. ${ }^{1}$ The symbiosis of the need of the state and society to mark their victims and the need of artists to express themselves in non-standard forms created a unique monument type. In the last decade, their abstract appearance is a kind of phenomenon that attracts the attention of citizens and artists from all over the world. From the initial photographs of Jan Kempenaers, ${ }^{2}$ through photographs of other artists, recorded music videos at the monument sites, amateur and scientific research of their origin, appearance and so on, we have undertaken serious endeavours to systematically record their existence and collect data about them. Today, some of the monuments are also a part of the tourist offer of the region. However, that is the global trend of today. We must say that similar actions had already been done in former Yugoslavia. Of course, with its specificities. As the time passed, the Yugoslav society became aware of the values of these memorials. These values were multiple - beside the basic value in keeping the eternal memory on the partisans and civilian victims, their high artistic value was recognized, as well as their tourist potential. According to the proclaimed policy of brotherhood and unity, monuments were one of the tools for their preservation. They commemorated the common struggle of all nations, as it was said in socialist Yugoslavia.

Over time, monuments gained certain popularity. Some of them practically became the main visual landmark of some area or historical event. Monuments began to appear on badges and other souvenirs, calendars, and the like. Publications were printed about them, including a special sticker album. Some of the printed publications were dedicated to one monument, others to all the memorials or to the most representative in one (wider or narrower) area.

Unlike nowadays, when we talk about monuments dedicated to the Second World War, the contemporary reader should pay special attention that in the time of socialist Yugoslavia they were called monuments of the People's Liberation War (PLW), or monuments to the Revolution, or both (monuments of the PLW and the Revolution).

In the mid-20 $0^{\text {th }}$ century printed media were one of the basic tools for spreading information. After WWII, information important to Yugoslav state authorities were printed in newspapers or on wall newspapers. In later decades, books also become an important part of media tools for transmitting certain information. On a global level, books managed to shape culture and society (Radojković i Miletić 2005). This was also recognised by the Yugoslav state and its organisations. From the end of the 50's state organisations and publishing houses started to print books about monuments dedicated to the PLW. We will present some of the earliest issues, and then, through a few examples, basic works on the popularization of the monuments through printed publications. Also, we will show the role of such publications in Yugoslav state propaganda.

\footnotetext{
${ }^{1}$ More about erecting of monument dedicated to happenings in Yugoslavia during WWII see in: Лајбеншпергер (2013), Manojlović Pintar (2014), Karge (2014).

2 Jan Kempenaers, Spomenik, Roma publications, Amsterdam, 2010; http://www.jankempenaers.info/ (accessed 26. 06. 2020).
} 


\section{FIRST BOOKS ABOUT MONUMENTS}

The first book about the monuments erected to the fallen soldiers during World War II appeared immediately after the liberation, in the year in which the war ended (1945). Although it was called Partisans' Monuments, it was not just a book about memorials. It was a general view on cultural and artistic activities during and after the war. The activities of artists who were members of the partisans, sympathizers of the resistance movement, or were in camps and prisons are shown, along with their artistic creations. Also, the work of architects on the renewal of the country and cultural workers on the opening of the museum of people's liberation was shown (Fisković 1945). Only one segment of the book was dedicated specifically to the monuments erected during and after the war. The text states that monuments are being built all over the country and draws attention to the fact that many of them are poorly artistically shaped. Several examples of well-executed memorials are given (Fisković 1945, 17-20). Although there are several reproductions in the book, none of them showed any of the existing monuments.

Immediately after the war, information about the erection of monuments was published in daily and periodical newspapers. Besides that, in various publications (books on the PLW, chronicles of places, biographies of killed partisans, etc.) that began to appear soon, information could be found about memorials erected in honour of someone, concerning a historical event, or a person, or a victim from one place (or at the certain place) and so on. However, it took more than a decade after the war for the memorials to become interesting enough to appear in specialized publications dedicated only to them. We notice two reasons for this. One is that by that time a large number of memorials had already been erected and the idea to register them arose. The second is the economic rise of the country, that occurred in the second half of the 1950s enabling the printing of such publications.

During 1958, the first two books (which we managed to find) dedicated specially to memorials appeared. One is dedicated to memorials on the territory of the City of Zagreb, and the other to one particular monument.

In 1958, the Museum of the City of Zagreb organized an exhibition Zagreb in honour of fallen fighters and victims of fascism. The exhibition presented busts, torsos and sculptures, also their models, castings and photographs dedicated to fallen fighters and civilians, erected until then in Zagreb and its surroundings. There was also a map on one wall of the exhibition room with the locations of those memorials. In addition, books printed on the topic of the PLW were exhibited. Alongside with the exhibition the book titled Monuments and memorial plaques in honour of students and events of the PLW in the area of Zagreb was published by the Museum of the City of Zagreb (Korac 1958a; Korać 1958b, 65; Franjković 1958). This booklet presents 168 memorials in the area of Zagreb and its surroundings. It is stated that all the monuments and memorial plaques, which had been erected up to that time in that area, are shown. Each monument and bust was described and the entire text from each of them was printed. For some of them information on who erected the memorial was given, or who the author was. Memorial plaques were represented only by name, location and the text from them transmitted. A smaller number of presented memorials was shown through black and white photograph (Korać 1958a; Franjković 1958). 


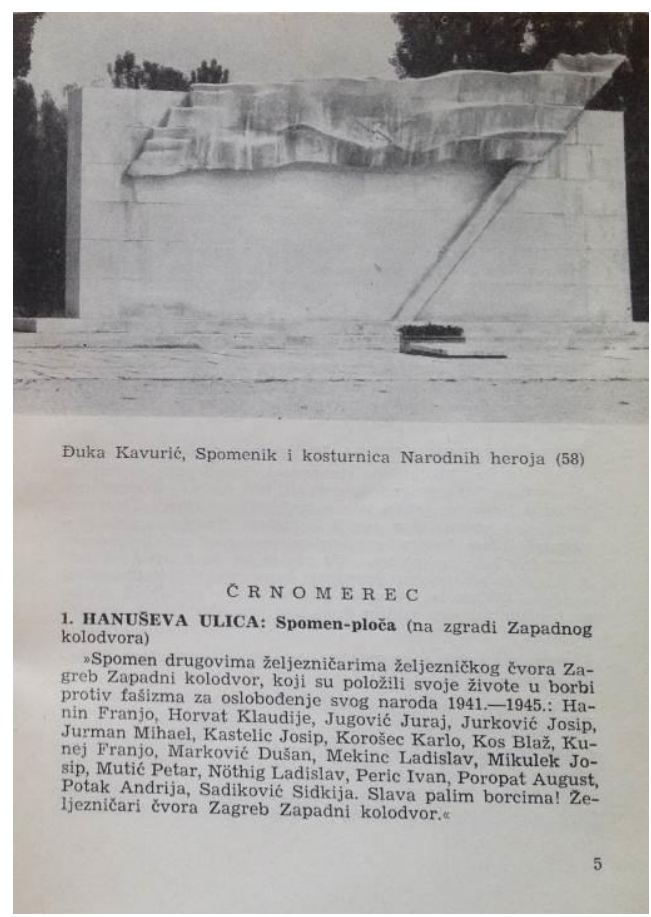

Fig. 1 One page from the book Monuments and memorial plaques in honour of students and events of the PLW in the area of Zagreb

During 1957, in the village of Kupirovo (near Srb and Gračac in Croatia), a monument with a memorial plaque dedicated to the inhabitants of that place who died during the Second World War was erected. After the unveiling of that memorial, the publisher, unknown to us, ${ }^{3}$ prepared a booklet of a total of 16 pages, entitled Memorial Book dedicated to the Celebration of the Unveiling of the Monument to Fallen Fighters in Kupirovo on July $27^{\text {th }} 1957$, which was printed in 1958. The booklet contains: a short introductory text about the erection of the monument; a transcript of a letter by which the Initial Committee for the erection of the monument called the inhabitants of that village to erect a monument; a list of fallen fighters in the village of Kupirovo in the PLW 19411945; and a list of donors. The last three pages contain black and white photographs from the unveiling of the monument. A photograph of the monument is also on the front cover of the book. Practically, this publication had a promotional character and its focus was especially on the act of erecting and unveiling the monument (Spomen knjiga 1958).

Next book about certain memorial was published in 1959. Regarding its content and review of the memorial itself, it was far more serious than the previous one. This book is named: The Monument of the People's Liberation War, but the cover-page reads The Monument to the People's Liberation War in Celje. As these titles suggest, it is dedicated to the monument of the PLW erected in Celje (Slovenia). The publisher was the Municipal

\footnotetext{
${ }^{3}$ We may speculate that the publisher was the Initial Committee for the erection of the monument. Committee was established in Belgrade, and the booklet itself was printed in that city.
} 
Board of the Union of Fighters of PLW from Celje, and it contains text in Slovenian, English, French and German. It is interesting that the book has no historical review of the events for which the monument was erected. There is only a text from the point of view of art historians that observes the monument and the socio-artistic trends during the period when it was erected. However, there are mentions of historical events in parts of the text, but for the purpose of explaining certain elements on the monument itself. The already established art historian, author Stane Mikuž, $\mathrm{PhD}$, prepared a detailed text about the monument. He briefly described the competition for choosing a solution for the monument, described in detail what was shown on it and finally explained the artistic distinctions and values of this work. The book is enriched with several illustrations. In addition to the photo on the front page, there are other black and white photos of the monument, close-up details, its models and sketches for the relief, then photos from the modelling, unveiling and Tito's visit. The first picture that the reader sees when they open the book is a photograph of the President of Yugoslavia Josip Broz Tito standing next to the monument. (Mikuž 1959)

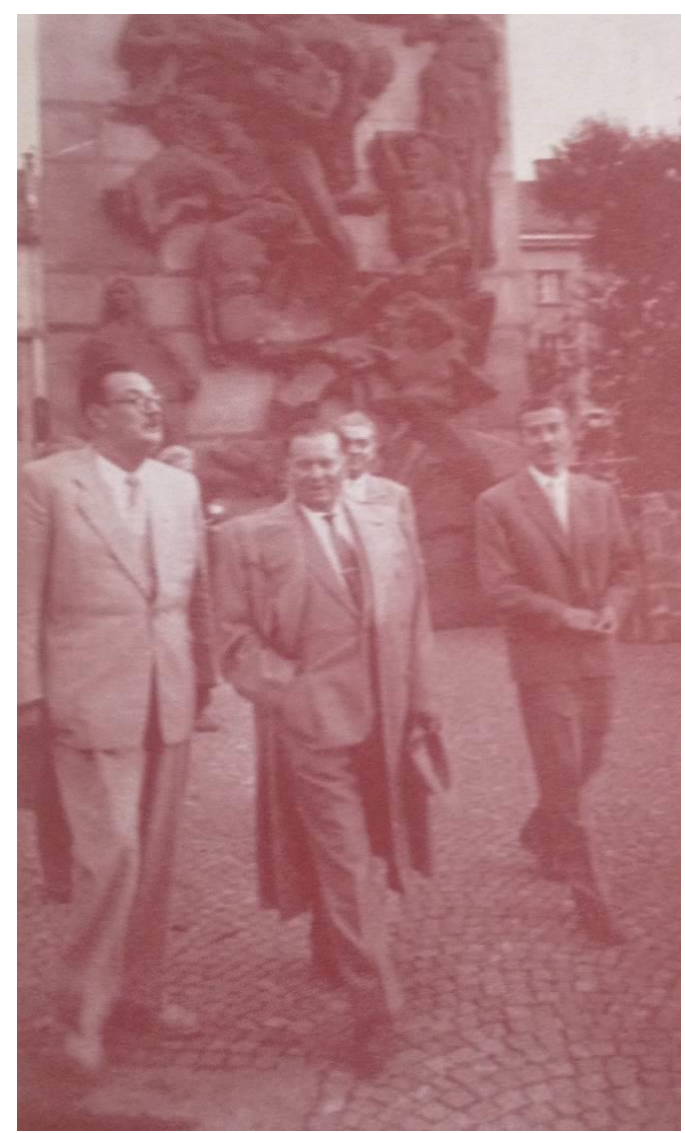

Fig. 2 Picture of Josip Broz Tito near the monument in Celje, from the book The Monument to the People's Liberation War in Celje 
Soon after these books, the first book which included monuments on the territory of one Yugoslav republic was published. Memories Carved in Stone. Monuments of the Workers' Movement and the People's Revolution in Croatia was published by the Information Office of the Executive Council of the Parliament of the People's Republic of Croatia in 1960. It was a state project in which the republic and lower regional authorities participated. The need to issue such a publication is explained with the words that the book "speaks with the voice of the dead who are still alive" (in Serbian: “...govori glasom mrtvih koji su živi”, Sjećanja u kamen uklesana, 9). Data for the book were collected by municipal authorities. Although the intention was to show all the memorials, the large amount of material that arrived forced the editorial office to make a selection of the most important ones. On the other hand, some municipal authorities did not send data. Because of that, for those municipalities not one memorial was represented in this publication. The book presents a total of over 2700 objects (Sjećanja u kamen uklesana, 301). The presentation of memorials was done according to the following principle: one or several sentences about the place itself; the text inscribed into the memorial itself; and information about when and who erected it (if these data were known). During the transmission of the texts from the monument, the names of the victims were not transferred when there was a larger number of them. Only information on how many names are listed on the memorial was printed then. At the end of the book, there is a block with black and white photographs in which a part of the memorial is presented. The first in that block is a photograph of the monument to Josip Broz Tito in Kumrovec, the work of sculptor Antun Augustinčić. The front page shows a monument in Drežnica (near Ogulin, Croatia), the work of sculptor Kosta Angela Radovani (Sjećanja u kamen uklesana).

These publications were merely an indication. A limited number of books with such content were published during the 1960s. In the 1970s, their number began to grow, but the largest number of publications was published in the second half of the 1970s and the first half of the 1980s. The slowdown of issuing such publications in the second half of the 1980s came to an almost sudden stop with the outbreak of wars in the Yugoslav republics. However, some books came out during the 1990s, but then in the new states.

Publications that provided information about all (or the most important) memorials in some areas mostly followed a similar matrix. Some of them included longer texts about events or personalities commemorated by that memorial, and some only basic historical information. Some printed only the texts from the memorial, with the added information that there is a list of the names of the victims on the memorial, and some printed those names in full. Some contained photographs of each of the displayed memorials, and some only for some of them. Considering the times in which they were printed, the vast majority contained black and white reproductions of the appearance of the memorial.

Publications dedicated to one monument or memorial complex had a similar matrix a historical review of the event or a biography of a person, then a description of the monument, along with photographs of it.

From the rest of the publications that came out in the 1960s, we will present only the capital one, issued by the Union of Association of Fighters of People's Liberation War (UAFPLW).

\subsection{Photo album "Yugoslavia. Monuments to the revolution"}

The idea for issuing a publication about the monuments erected to the PLW in Yugoslavia came from the Council for Taking Care of the Revolutionary Traditions of 
the PLW of UAFPLW in 1964. Their basic idea was to show through such a publication the contribution of Yugoslavia during the Second World War, as well as the course and greatness of the liberation struggle. It was primarily meant for a foreign audience, so the distribution of the publication was planned for distribution on foreign markets, but without neglecting the national one. The publication was planned as part of the upcoming celebration of the $20^{\text {th }}$ anniversary of victory over fascism (planned for the following year, 1965). In addition, the publication was supposed to be another tool in the fight against fascist revisionism throughout the world, and in the education of the local youth. It was also considered that the existing monuments of the struggle and suffering of the Yugoslav people express the care of the Yugoslav society in marking important places from the war, an extraordinary rich cultural fund, and creativity inspired by the revolution. Such a publication would be important for popularizing Yugoslavia's contribution to the fight against fascism during the Second World War and the popularization of the artistic achievements inspired by that struggle. Thus, the publication should satisfy the cultural and political needs of Yugoslav propaganda both in the country and abroad. Although the basic idea was the popularization of the PLW and its monuments, UAFPLW did not plan to make a book that would be available to everyone, but an exclusive, quality edition, with a representative character. It was expected that only certain institutions and organizations would buy it (AY - 297 II - 323 - 1964).

It was decided that the form of the publication would be a photo album. Similar western publications with high artistic and technical levels provided the model. It was considered that twenty years after the war, it was impossible to show the struggle and suffering exclusively in a naturalistic way by showing hangings, shootings, excavated graves, ruins, burned houses, etc. Since there were already a large number of publications across Europe that portrayed suffering through documentary photography, it became difficult to show the specifics of Yugoslavia. Therefore, it was considered that the presentation of the struggle through the erected monuments would be a fresh outlook on dealing with such a topic (AY - 297 II - 323 - 1964).

Practically, the basic idea had a political character - the popularization of the struggle of the Yugoslav people against fascism. The publication of photographs of monuments was just a tool through which that struggle was to be presented. The need to show the artistic achievements of these monuments and to show in general how the Yugoslav society maintained the memory of the war and the revolution were deeply subordinated to the basic idea.

Interior Yugoslav benefits of this publication were seen in its ability to influence the processes of erecting future monuments. The album was supposed to be an impulse for continuing monument erection. At the same time, it should have influenced avoiding the appearance of low-quality and non-artistic monuments. The intention was also that the printing of such a book should encourage other Yugoslav publishers and organizations to issue similar publications, with the aim of further popularization (AY - 297 II - 323 - 1964).

The initial idea was to present monuments from all Yugoslav republics (in proportion to the historical significance of the struggle within the republic) and several of them erected abroad. It was necessary to compose well the historical significance and artistic content of the monument. The Album was supposed to contain top artistic and architectural works of various artistic styles. If necessary, the artistic shortcomings of the monument should have been compensated by a good director of photography, all in order not to miss a significant historical event. The republican committees of UAFPLW were 
asked to determine the most important monuments that would be included in the publication (AY - 297 II - 323 - 1964).

The publication funding was provided through the Federal Board of UAFPLW, which was to cover the publication, the funding of the sessions of the Yugoslav Editorial Board and reviews of historiographical materials. It was planned that the republican representatives of UAFPLW would take care of the financing of the preparatory works (costs of recording approved monuments and obtaining historical data on selected monuments, as well as possible other costs that would appear) (AY - 297 II - 323 - 1964).

Miloš Bajić, a professor at the Academy of Fine Arts, was appointed as editor. There were several editorial boards. The main was the Federal Board of UAFPLW, and each Republic had its own. They consisted of important artists and cultural workers of the former Yugoslavia. The co-publisher was the publishing house Svjetlost from Sarajevo (AY - 297 II - 323).

When the preparation of the edition started, it encountered numerous problems, so the printing itself was postponed year after year. Finally, it appeared in 1968, three years later than the originally planned year of printing.

One of the problems concerned the required photographs, which should have been taken in an artistic manner. The initial idea was that the photographers would be engaged by the republican UAFPLWs. But not all the republican organizations were precise, nor hired photographers on time. Also, agreement on a uniform criterion for the photographs lasted for a long time. Some of the submitted photos were not of acceptable quality for the editorial office. A special effort was made to ensure that all photographs were of an appropriate artistic level and that they faithfully show the artistic values of the monument. Due to all that, the Federal Board organized the re-photographing of some monuments. As larger funds were needed to go abroad, the Federal Board attempted to collect photos of certain monuments through Yugoslav embassies. However, when the photographs came, there was also a problem of inadequate quality of the submitted photos. In addition, not all photographs of the planned monuments were obtained (for example, the memorial at El Shatt in Egypt) (AY - 297 II - 323).

Another problem concerned the different criteria among republican organizations for the selection of monuments. Some of the proposed monuments were evaluated by the Federal Board as insufficiently valuable. Also, it was evaluated that the republic committees failed to propose some valuable works. During the work on the book some new valuable monuments were erected. Due to all that, the Federal Board itself deleted some monuments from the lists, and added others (AY - 297 II - 323 - 1964; AY - 297 II - 323 - 1965).

According to the plan, the Album was printed in 9 languages: Serbo-Croatian, Slovenian, Macedonian, Italian, Hungarian, Albanian, Russian, French and English. Practically, they were: three official Yugoslav languages, three languages of national minorities in Yugoslavia and three foreign languages (AY - 297 II - 323). ${ }^{4}$

At the very beginning of the Album Yugoslavia. Monuments to the Revolution, there is a short introductory text of the Editorial Board, with an explanation of the need for such a publication and the manner in which the displayed monuments were selected.

\footnotetext{
${ }^{4}$ The names of publications by languages were: Serbo-Croatian: Jugoslavija. Spomenici revoluciji; Slovenian: Spomeniki revoluciji. Jugoslavija; Macedonian: Спомениии на револуиијата. Jугославија; Italian: Jugoslavia. Monumenti alla rivoluzione; Hungarian: Jugoszlávia. A forradalom emlékmüvei; Albanian: Jugosllavia. Monumente revolucionit; Russian: Югославия. Памятники револющии; French: Yugoslavie. Monuтепts à la Révolution and English: Monuments to the revolution. Yugoslavia.
} 
Then there is a corpus on 248 pages with photographs of monuments or important places from the PLW and the revolution. All reproductions are printed in black and white. Only the cover of the publication is partially in color (with a photograph of a monument in Podgarić, Croatia). The Album presents a total of 101 monuments or sites. Due to the previously described need to present all the most historically significant places, several of them were not presented with photographs of monuments, since they did not have monuments that could represent them..$^{5}$ Photographs were printed over the whole page, except for four monuments when the photographs extend on two sides. ${ }^{6}$ They were grouped in blocks of one to five monuments or sites. A certain number of monuments is presented with one photograph, and some with more. Some are presented in full, and some only in detail. After the photographs, there is information about the authors of the monuments, and then historical information about the events or personalities to whom the monuments themselves are dedicated. At the end there is a Catalog of photographs printed in the form of a flap, so it is possible to follow it parallel by looking at the photos (Bajić 1968).

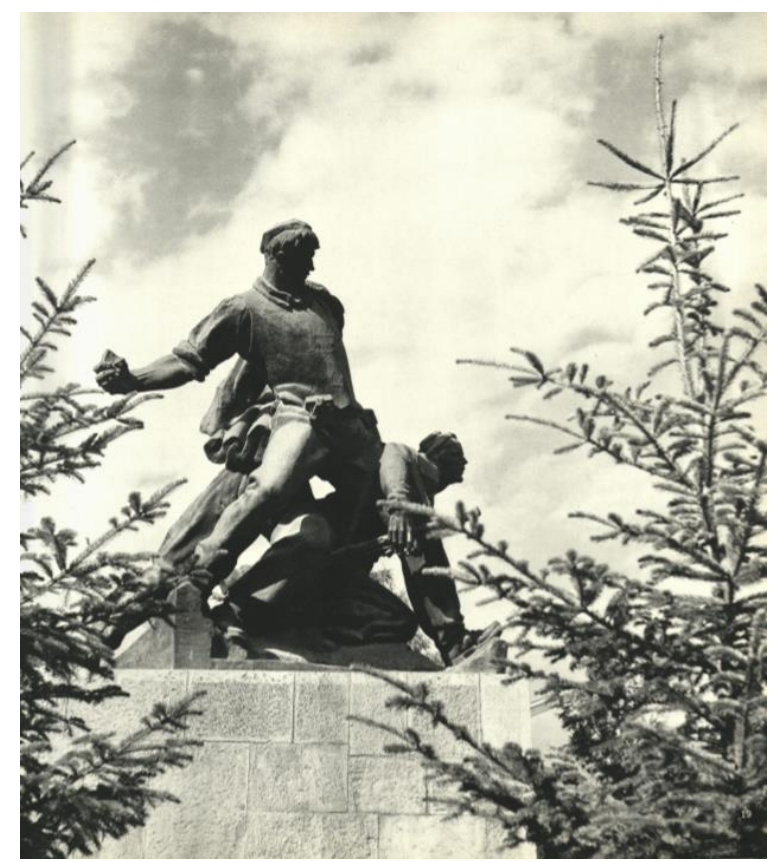

Fig. 3 An artistic picture of the monument in Prijepolje, from the album Yugoslavia. Monuments to the Revolution

\footnotetext{
${ }^{5}$ Thus, Kozara is shown trough the artistic photography from the war (made by Žorž Skrgin), Neretva with a picture of the river canyon, Jajinci with a picture of the trail over which victims were taken to be shot, Jajce and Bihać with pictures of the cities, Drvar with a house by the cave, Prohor Pčinjski Monastery with a picture of the monastery complex from a distance, partisan hospitals in Cerkno and Petrova Gora trough preserved buildings, Sutjeska and Dachau trough a model of future monument and Ausvic with a sculpture that was on display in the Yugoslav part of the museum of the former camp.

${ }^{6}$ Monument at Šehitlucima near Banja Luka, Monument in Dotraščina near Zagreb, Monument in Podgarić (Moslavina, near Bjelovar in Croatia) and the model of a monument at Tjentište (Sutjeska).
} 


\section{TOURISTIC GUIDES}

In the middle of the 1970s, it was recognized that changes had to be made in the Yugoslav tourist offer. There was unbalanced structural development of the tourist economy. The reason for that was the biggest concentration of tourist offer and consumption on the Adriatic coast and the dominant development of tourism infrastructure in that area. At the same time, the increased arrival of foreign tourists was exclusively in that area, with a distinct seasonal concentration during July and August. The development of tourism on the Adriatic coast caused a partial neglect of the development of continental tourism. In order to equalize and diversify the development of the entire tourist infrastructure, but also to support underdeveloped areas, the state authorities decided to include memorial tourism more significantly in the overall tourist offer. (Rakita 2019, 91-108; Stanković 1990, 76-77, 79-80, 129, 133, 143-377; Kobašić 1987, 26-36, 41-49, 53-58, 95-96).

A certain tourist infrastructure already existed at some monuments and memorial complexes, made for the visitors of those memorial places. The intention was to include them additionally in the tourist offer of the area in which they were located. Also, those who visit such places out of piety could be informed and stimulated to visit other sights in that area. In addition, special memorial tourist routes were prepared. Following their trajectory, the interested tourist could visit several different memorials.

One of the important activities in order to incorporate memorial tourism in the overall tourist offer was their mass inclusion in the tourist propaganda materials of a city or region, and then the printing of tourist guides dedicated exclusively to them (Rakita 2019, 102).

An example of a tourist guide from the beginning of the 1970s, which includes a memorial space important for the revolution, is the one for the Croatian town of Jajce, where the creation of a new state organization was declared. A larger part of the guide under the name Jajce, printed in 1971, is dedicated to the natural and cultural heritage of Jajce and its surroundings. A small part of the publication is dedicated to the historical value of the place, but it is physically at the very beginning, actually preceding the other descriptions (Jajce 1971). During the same year the tourist guide Through Kruševac and its surroundings was printed. In it we can read about the past of Kruševac and its surroundings, and the sights that can be visited there. One segment, approximately the same size as the other sights of that area, is dedicated to Slobodište, the place where civilians from Kruševac were shot to death during the Second World War (Jugović 1971). Over the time, the intention to include the monuments of the PLW in the tourist offer resulted in larger appearance of monuments in tourist guides. Thus, in 1978, a new tourist guide for Kruševac and its surrounding was published. In that guide, titled Kruševac and its Surroundings. Cultural and Historical Monuments, the presence of monuments of the PLW was significantly bigger than before and occupied a larger part of the publication than all the other sights of that area (Stošić 1978).

The printing of tourist guides dedicated exclusively to one memorial was done by the institutions that took care of a certain memorial complex, municipalities and cities on whose territory the memorials were located, and publishers specializing in tourist propaganda. Thus, the institution Kragujevac October Memorial Park printed several guides through the memorial park of the same name in Šmarice in Kragujevac. The publishing house Turistkomerc from Zagreb, within its Library Small Tourist Monographs, printed guides for several memorial complexes, among which were the Memorial Park Petrova Gora and the Memorial Place Jasenovac. These guides contain numerous coloured photographs of 
contemporary scenes, historical data about the place and area, with a special emphasis on the Second World War, and additional information about the monuments in the region. The guide for Petrova Gora also contains tourist itineraries with instructions on how to get to that memorial, and what can be visited in its surroundings with a description of that place. Both editions contain a map of the environment. On their covers are monumental objects erected in these memorial complexes (Trivunčić 1975; Dakić 1982). The most significant undertaking in the field of printing the tourist guides was carried out by the Belgrade publishing house Turistička štampa, which dedicated an entire library to the memorials of the PLW and the revolution.

\subsection{Tourist Guide Library "Monuments of the Revolution"}

The publishing company Turistička štampa (Tourist Press) was founded in 1953 with the aim of printing tourist propaganda materials. In time, it became one of the most important publishers of that kind in Yugoslavia. Its publications covered all parts of the country and were distributed in the country and abroad (Turistička štampa 1953-1983, 1983).

During 1976, the institution Sutjeska National Park issued a tourist guide about the national park of the same name, which included the most important memorial complex in Yugoslavia - Tjentište, dedicated to the Battle at Sutjeska from 1943. It is a short, smallformat publication (of 32 pages). The editorial equipment of the book was made by the Turistička štampa (Jokić 1976). There was no indication on it that it was part of some special library. In the following year, the Sutjeska National Park, this time together with the Turistička štampa as a co-publisher, issued the second edition of this book, almost in the same way as the previous, but with the indication that it is part of the library Monuments of the Revolution (Jokic 1977c). This was the beginning of the publication of the library (or publication series), which gained great popularity in the former Yugoslavia. Within it, 29 tourist guides were printed, in 55 editions, and with a total circulation of over a million and a half copies, and one monograph (which gathered all the published guides). The circulation of individual publications ranged from 5,000 to 120,000 copies. $^{7}$

The guides were dedicated to the following monuments, memorial complexes, cities, sites or a group of monuments or sites: the Sutjeska National Park (Jokić 1976); Memorial Place Jasenovac (Jokić 1978c); Bihać (Jokić 1977a); Kragujevac October Memorial Park (Jokić 1977d); Drvar (Jokić 1977b); Petrova gora Memorijal Park (Dakić 1977); Neretva - Makljen and Jablanica - Prozor (Jokić 1979b); Monuments of the Revolution on Kosovo (Hardi 1978a); Durmitor National park (Jokić 1978a); Boško Buha Memorial Area (Vukotić 1979); Kozara Nacional park (Jokić 1978b); Jajce (Ajder 1978); Memorial Park Kumrovec (Mitić 1979; Jokić 1986b); Mrkonjićgrad (Jokić 1979a); Kraljevo Memorial Park (Jovetić 1979); Foča (Jokić 1980); Bubanj Memorial park and The Red Cross concentration camp in Niš (Stamenković 1981); Rudo (Jokić 1981a); Mitar Trifunović Učo Memorial House in Bosanski Šamac (Jokić 1981a); Kočevski rog (Jokić 1982a); Titovo Užice (Bulatović i Poznanović 1982); Bijeli PotociKamensko Memorial Area (Dakić 1983); Biokovo Memorial Area (Urlić i Gareljić 1983);

\footnotetext{
${ }^{7}$ the largest nominal impression was of the publication for the Kragujevac October Memorial Park - 120,000 (although the question is whether it was a real impression, since it was planned to be printed and translated into other languages, which did not happen). The next in size are the impressions for the Sutjeska National Park and the Kozara National Park - with 100,000 copies each. The largest number of single publications was printed in an impression of 20,000 copies.
} 
Korčanica Memorijal zone and Podgrmeč Museum (Jokić 1983); Kadinjača Monument (Stanimirović, Marinković 1984); Kruševo (Ilinden Uprising) (Поповски 1983); Bela Crkva Memorijal and Stolice Memorijal (Jeremić 1989); Šekovići (Simonović i Miljanović 1984) and Workers House and Dudik Memorial Park in Vukovar (Buljan i Marić 1984).

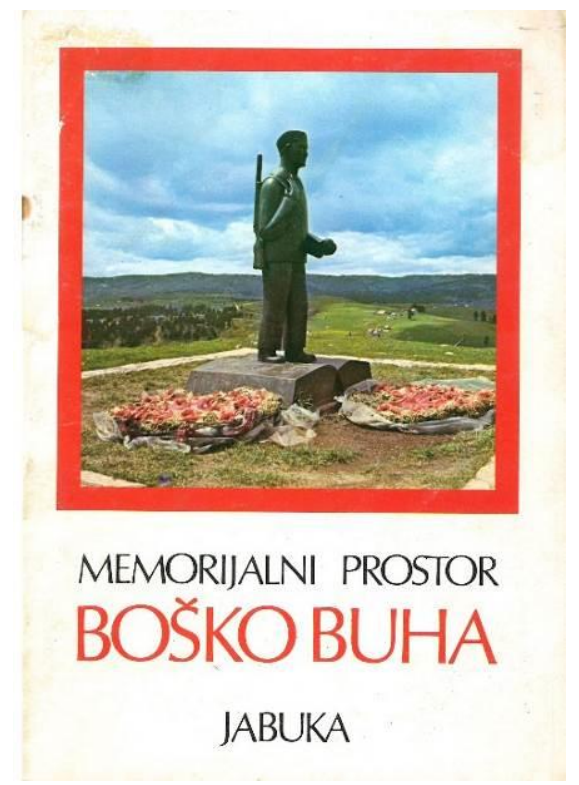

Fig. 4 The cover page of tourist guide for Boško Buha Memorial area, Jabuka

The guides were printed in the languages used in Yugoslavia: Serbo-Croatian, Slovenian, Macedonian and Albanian, and in foreign languages: English and Russian. ${ }^{8}$ Except for one, all the editions had a Serbo-Croatian version. The exception was a guide dedicated to the Ilinden Uprising, which was printed only in Macedonian (Поповски 1983). Тwo guides also had editions in other languages used in Yugoslavia - one in Slovenian - Kočevski rog (Jokić 1982b); other in Albanian - Monuments of the Revolution on Kosovo (Hardi 1978b). One guide, Kozara National Park, had editions in two other languages - English and Russian (Jokić 1986a, Йокич 1986), and two guides, for Memorial park Kumrovec and Bubanj Memorial park, had editions translated only into English (Mitić 1982; (Stamenković 1982).

The authors of the publications were already acknowledged writers of tourist guides, scientists, publicists, and also people who were beginners in writing such publications. The writer who wrote the most texts was Gojko Jokić. Even before the creation of this library, he was the author of notable tourist guides printed by the Turistička štampa.

According to the publisher, the basic idea of the Library Monuments of the Revolution was to bring the sites of the PLW, which are marked with monuments or arranged as memorial complexes, in a popular way, especially to the young generation. The intention

\footnotetext{
${ }^{8}$ The guide for Kragujevac October Memorial Park was not printed in other languages (English, French, Russian and German) although in the Serbian edition it was written that they were (Jokić 1977d, 2).
} 
was to show, beside the memorial, the total tourist offer of that locality (Turistička štampa 1953-1983, 1983, 34).

The small-format guide $(17 \times 12 \mathrm{~cm} ; 32$ pages $)$ is suitable for carrying and reading. The cover design is extremely likable and attractive. It is colored in white. In the top two thirds, there is a color photograph framed by a thick red line. In the lower third there is the title of the guide, written in two font sizes and colors - a larger red and a smaller black. In addition, most editions had an emblem next to the title. Somewhere, there were emblems of institutions that existed in that area (museums, memorial complexes, national parks ...), in some the coats of arms of the cities, in some the Order of the People's Hero, etc.

The texts in each guide were made according to a unique matrix, mainly in this order: description of one or more events from the PLW, the presentation of memorials or memorial complexes, data about other cultural and natural sights (including other memorials), and finally tourist information (available accommodation, restaurants, health stations, banks, services, gas stations, bus and train stations, etc.). Some guides had suggested tourist routes. Most of them had maps. Somewhere there were maps of the memorial complex, or of surrounding areas. Some publications also provided an overview of older history, but this is shown after the segment about the PLW. Earlier history was written before the part about PLW only if it presented the development of the workers' movement in the area in which the memorial is.

Most of the editions were dedicated to some anniversary. It was either the anniversary of a historical event related to that memorial or some more general date related to the Yugoslav revolution or the jubilee related to Josip Broz Tito. For example, the edition about the Durmitor partisan republic is dedicated to the $35^{\text {th }}$ anniversary of the liberation of Žabljak (Jokić 1978a). Some dedications were more general, unrelated to the jubilee. Thus, the editions for the Memorial Place Jasenovac had the message "Let's not forget..." (Jokić 1978c), and for the Memorial Complex Stolice "Here Serbia said freedom ..." (Jeremić 1989).

With the intention of presenting all the important monuments and memorial complexes of the PLW in one place, along with their tourist valorization, the Turistička stampa, together with a number of institutions that took care of memorial spaces, printed the monograph Yugoslavia. Monuments of the Revolution (Tourist Press 1953-1983, 1983, 35; Jokic 1986c). The monograph presented all the places that were shown in the individual guides. Due to space restrictions, the texts were significantly shortened in relation to the individual guides. In addition, a number of other places or localities were added: Belgrade, Brioni, Cerkno, Cetinje, Glamoč, Jastrebarsko, Kolašin, Ljubljana, Mostar, Novi Sad, Prilep, Sarajevo, Vis and Zagreb. Brief descriptions of a larger number of important memorials from whole the country have been added. At the end, a proposal for several itineraries was given. A very significant contribution of this edition was the map of Yugoslavia. The locations of the memorials were presented on it, with a miniature display of the memorial itself, or some other object significant for that site (Jokić 1986c).

The awards, which this library received, speak of its importance and success. In March 1978, at the International Fair of Tourism and Sports in Sarajevo, it received the Golden Plaque. Six years later, in 1984, UAFPLW awarded the library with the $4^{\text {th }}$ July Plaque for Journalism (Jeremić 1989, 2).

The Library of the Monuments of the Revolution also had three sub-libraries - Timo među nama (Tito among us); Istrojske fotografije (Historical Photographs) and Trajanja (Lastings). The publications printed in these sub-libraries did not speak directly about the 
memorial complexes erected on the war sites and places of importance due to the events during the war. These issues were dedicated to Josip Broz Tito, his native village Kumrovec and to the events of the war itself.

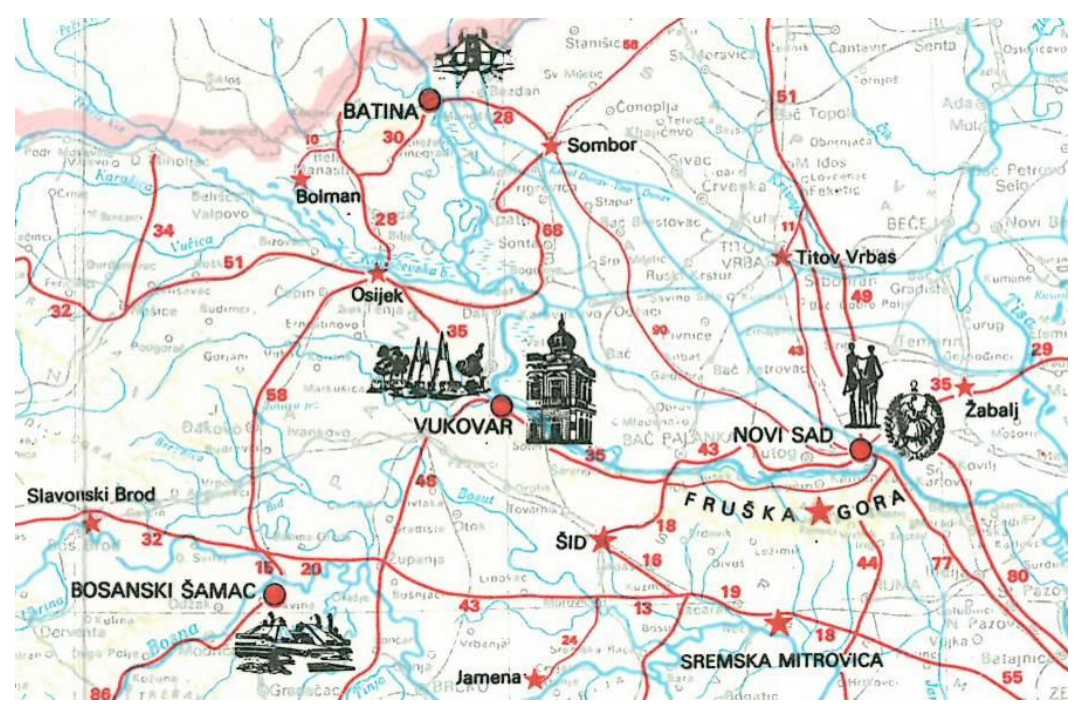

Fig. 5 A cut-out of a map from the monograph Yugoslavia. Monuments of the Revolution

\section{THE STICKER ALBUM}

The last of the significant phenomena of popularization of the PLW monuments through the printed media is the Sticker Album 1892-1937-1977. Spomenici Revolucije. Prva sveska (1892-1937-1977 Monuments of the Revolution. The first volume), published in 1978. The publisher was the publishing company Sava Munćan from Bela Crkva. Publishing Council included persons from the UAFPLW, museum and the institute for the Protection of Cultural Monuments. The album was intended for children, but it had strong ideological connotation. First of all, there was the intention to acquaint children with the monuments dedicated to the PLW. Then, through memorials, children would get familiar with the PLW itself and the sacrifice given for freedom during the war. The ideological matrix can clearly be recognized through listed years in the name of the Album itself. The first year is the birthyear of Josip Broz Tito, the second one was Tito's coming to the top of the CPY, and the third - Tito's $85^{\text {th }}$ birthday and the year of celebration the $40^{\text {th }}$ anniversary of his placement at the head of the CPY $(1892-1937-$ 1977. Spomenici Revolucije, 1978).

A total of 252 stickers had to be collected - 36 with a monument from every republic, plus 18 from two provinces. The republics and provinces were arranged in alphabetical order, and the monuments themselves within that in the same alphabetical matrix based on the name of the place where they are located. As in other publications, not only monuments in a narrow sense were shown, but also museum buildings of significant events, ossuaries and cemeteries, original objects from the PLW (houses, hospitals, remains of the bridge on the Neretva...), etc. The photos in colour of the memorials on the stickers were followed by the appropriated 
text printed in the album. In addition to the name of the place and the monument, some of the following information was given: a description of the monument, its symbolism, overview or description of historical events or the person to whom it was dedicated, and finally the name of the author of the monument. On the back cover of the album a map was printed with the contours of the Yugoslav border and marked places of the memorials (1892-1937-1977. Spomenici Revolucije, 1978).

Second and third volumes of the album were planned, but were never released.

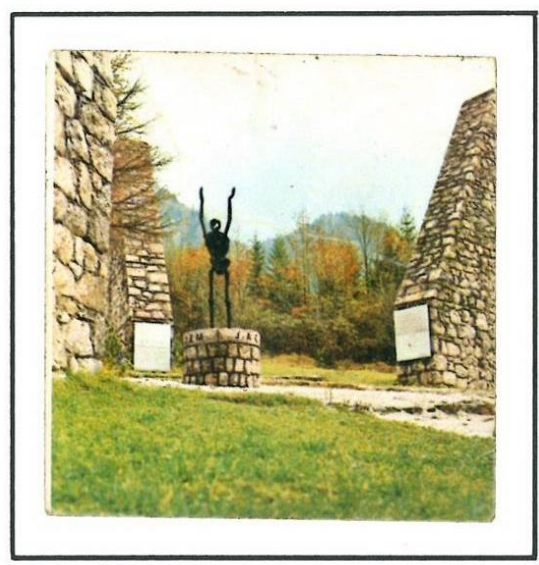

LJUBELJ

161.

Spomenik na mestu koncentracionog logora

Nemci su 1942. počeli na Ljubelju sa prinudno mobilisanim radnicima izgradnju drumskog tunela ispod Karavanki. Jula 1943. doveli su tu i oko 100 zarobljenika iz koncentracionog logora Mathauzen, u stvari osnovali ogranak tog zloglasnog bio je organizovan prema propisima centralnih nemačkih koncentracionih logora. Broj logoraša se iz dana u dan povećavao, tako da je do juna 1944. porastao na oko 1.000 . Najviše je bilo Francuza, zatim Belgijanaca, Poljaka, Rusa, Nemaca, Jugoslovena i drugih. Ne zna se koliko je interniraca pobijeno $i$ koliko ih je pomrlo u ovom logoru. Spomenik je podignut na livadi ispod Ljubelja gde je i bio logor.

Autor: Boris Kobe, arhitekta

Fig. 6 A cut-out from the Sticker Album 1892-1937-1977. Monuments of the Revolution.

\section{CONCLUDING REMARKS}

Considering the publications on the monuments of the PLW presented in this paper, as well as many others related to the same topic, we can conclude that the intention for their publication has an informative and propaganda character. Its informative character is seen in purely giving basic or broader information about a particular memorial(s). Their propaganda function was twofold. The first propaganda function was to spread information about the monuments themselves, including all their values - historical, artistic, and even ambiental, and to invite people to visit them. This was practically a popularisation of monuments. The second one was recognized within the state's propaganda for defending the socialist system in the country. The state and the CPY had a need for remaining the communist structures in power and that was strongly supported by asserting the main role of the CPY in World War II (the leading role in the successful struggle for the liberation of the country from the occupiers, and then the revolutionary change of government). The presentation of the monuments was another tool used to show that struggle. Talking about the monuments, it was unavoidable to show why they were erected. In that way, the struggle and sacrifice of partisans and communists stood out even more. Another aspect of this propaganda was the cult of Josip Broz Tito. It was strongly supported through such publications. First of all, as in textbooks and other various publications, on the first pages there was a picture of Tito or a quote from one of his speeches. The image and the quote were mostly related to the topic of the publication itself, but not necessarily. Specifically, for the memorials, it would be a picture of Tito's visit to that monument or memorial complex, or his picture in that area during the war. Sometimes 
the representation of a monument dedicated to him would have a slight advantage over others in the way it was presented (the prominent position of the description and image in the publication, a far more affirmative tone in the text, larger text of the description than for other monuments...). This propaganda role became especially important for the younger generations, born in the decades after the war, who did not find ruins and ashes, who grew up in a society in which war wounds were already partially healed and war victories and casualties were far away. Thus, it was harder for children to understand and accept the importance of struggle and sacrifice. Of course, we must not forget the personal feelings of the authors of these publications. It is certain that there was a kind of gratitude towards the victims and a need to retrieve those victims from oblivion by writing about monuments, but we cannot estimate how often, and to what extent, this was the case.

The large circulation of some of these publications, institutional support from the federal, republican and local authorities and UAFPLW, justify the need for such an issue in society. State and personal needs overlapped. The state's need was twofold - propaganda, as well as sense of duty to repay to the victims with dignity in that way. Although the second was an integral part of first, we are here trying to emphasize their human side, separated from political propaganda. We believe that the personal framework was related to the sense of honouring the victims, and within that there was a need for information about how the state and society paid honour to them by erecting memorials.

\section{REFERENCES}

1892-1937-1977. Spomenici Revolucije. Prva sveska. Bela Crkva: Grafičko izdavačka Radna organizacija Sava Munćan, 1978.

Ajder, Dragan. Jajce, grad II zasjedanja AVNOJ-a. Jajce i Beograd: Muzej Drugog zasjedanja AVNOJ-a i NIŠRO „Turistička štampa”, 1978.

Bajić, Miloš, ed. Jugoslavija. Spomenici Revoluciji. Beograd I Sarajevo: SUBNOR Jugoslavije i Svjetlost, 1968.

Bulatović, Božo i Rade Poznanović. Titovo Užice. Period Užičke republike. Titovo Užice I Beograd: OOUR Muzeji "Narodni muzej”, OOUR spomenika Kadinjača i NIŠRO Turistička štampa, 1982.

Buljan, Zdenka and Ružica Marić. Radnički dom. Memorijalni park Dudik, Vukovar. Vukovar i Beograd: Općinsko vijeće Saveza sindikata Hrvatske, SIZ kulture općine Vukovar, Gradski muzej Vukovar i NIŠRO Turistička štampa, 1984.

Dakić, Mile. Memorijalni park Petrova gora. Vojnić i Beograd: Memorijalni park Petrova gora i NIP „Turistička štampa”, 1977.

Dakić, Mile. Memorijalni park Petrova gora. Vojnić I Zagreb: Memorijalni park Petrova Gora i Turistkomerc, 1982.

Dakić, Mile. Spomen-područje Bijeli Potoci-Kamensko, Titova Korenica. Titova Korenica I Beograd: Spomenpodručje Bijeli Potoci - Kamensko i NIŠRO Turistička štampa, 1983.

Fiskovic, Cvito. Partizanski spomenici. Split: Slobodna Dalmacija, 1945.

Franjković, Pavle. "Spomenici i spomen-ploče u čast učesnika i događaja NOB na području Zagreba". Vijesti Društva muzejsko-konzervatorskih radnika NR Hrvatske 3 (1958): 85

Hadri, Ali. Spomenici revolucije Kosovo. Priština: Turistički savez Kosova,1978a.

Hadri, Ali. Përmendoret e revolucionit Kosova. Prishtinë: Lidhja Turistike e Kosovës, 1978b.

Йокич, Гойко. Начиональный парк Козара: Приедор. Prijedor i Beograd: Nacionalni park Kozara i NIP „Turistička štampa”, $1986 .{ }^{3}$

Jajce. Jajce: Skupština opštine Jajce, 1971.

Jeremić, Mića. Memorijalni spomenik Bela Crkva. Memorijalni spomenik Stolice, Krupanj. Krupanj i Beograd: Narodni univerzitet „Ustanak” i NIŠRO Turistička štampa, 1989.

Југовић, Милутин Р. Кроз Крушевац и околину. Крушевац: Едиција „Багдала“, 1971.

Jokić, Gojko. Bihać. Grad Prvog zasjedanja AVNOJ-a. Bihać i Beograd: Turističko društvo Bihać i NIO "Turistička štampa", 1977a.

Jokić, Gojko. Drvar, grad-heroj. Drvar i Beograd: Spomen-muzej „25. maj 1944.“ u Drvaru i NIP “Turistička štampa", $1977 b$. 
Jokić, Gojko. Durmitorska partizanska republika, Nacionalni park Durmitor, Žabljak. Žabljak i Beograd: "Industrijaimport", Titograd - OOUR "Durmitor" i NIŠRO “Turistička štampa”, 1978a.

Jokić, Gojko. Foča. Fočanski period narodnooslobodilačke borbe. Foča i Beograd: Muzej Fočanskog perioda NOB i Turistička štampa, 1980.

Jokić, Gojko. Grmeč, Korčanica, Sanski Most, Jasenica, Bosanska Krupa. Sanski most i Beograd: Memorijalna zona Korčanica, Bosanska Krupa: Muzej Podgrmeč u NOB, Jasenica i NIŠRO Turistička štampa, 1983.

Jokić, Gojko. Kočevski rog. Baza 20, Novo mesto. Novo mesto i Beograd: „Krka”, TOZD Zdravilišča i NIŠRO Turistička štampa, 1982a (Serbo-croatian edition).

Jokić, Gojko. Kočevski rog, Baza 20, Novo mesto. Novo mesto i Beograd: „Krka”, TOZD Zdravilišča i NIŠRO Turistička štampa, 1982 b (Slovenian edition).

Jokić, Gojko. Mrkonjić-grad. Grad I zasjedanja ZAVNOBIH-a. Mrkonjić-grad i Beograd: Narodni univerzitet i NIŠRO Turistička štampa, 1979a.

Jokić, Gojko. National park Kozara, Prijedor. Prijedor i Beograd: Nacionalni park Kozara i NIP „Turistička štampa", 1986a. ${ }^{3}$

Jokić, Gojko. Nacionalni park Kozara, Prijedor. Prijedor i Beograd: Nacionalni park Kozara I NIP „Turistička štampa", 1978b.

Jokić, Gojko. Nacionalni park Sutjeska Tjentište. Tjentište: Nacionalni park „Sutjeska”, 1976.

Jokić, Gojko. Nacionalni park Sutjeska Tjentište. Tjentište i Beograd: Nacionalni park „Sutjeska” i NIP Turistička štampa, 1977c.

Jokić, Gojko. Neretva-Makljen, Jablanica-Prozor. Sarajevo i Beograd: Muzej revolucije Bosne i Hercegovine i NIŠRO Turistička štampa, 1979b.

Jokić, Gojko. Jugoslavija. Spomenici Revolucije. Turistički vodič. Beograd: Turistička štampa, 1986c.

Jokić, Gojko. Spomen-dom Mitar Trifunović Učo, Bosanski Šamac. Bosanski Šamac i Beograd: Spomen-dom "Mitar Trifunović Učo" i NIŠRO Turistička štampa, 1981a.

Jokić, Gojko. Spomen-park Kragujevački oktobar. Kragujevac i Beograd: Spomen park „Kragujevački oktobar“ i NIP „Turistička štampa“, 1977d.

Jokić, Gojko. Spomen-park Kumrovec, Kumrovec. Kumrovec i Beograd: Spomen park Kumrovec i NIŠRO Turistička štampa, 1986b.

Jokić, Gojko. Spomen-područje Jasenovac. Jasenovac i Beograd: Spomen područje Jasenovac i NIŠRO „Turistička štampa”, $1978 \mathrm{c}$.

Jokić, Gojko. Rudo, grad Prve proleterske NOU brigade. Rudo i Beograd: Dom kulture Prve proleterske i NIŠRO Turistička štampa, 1981a.

Jovetić, Rade i Miro Stamenović. Spomen-park Kraljevo. Kraljevo i Beograd: Skupština opštine Kraljevo i NIŠRO „Turistička štampa“, 1979.

Karge, Hajke. Sećanje u kamenu - okamenjeno sećanje? Beograd: Biblioteka XX vek, 2014.

Kempenaers, Jan. Spomenik. Amsterdam: Roma publications, 2010.

Kobašić, Antun. Turizam u Jugoslaviji. Razvoj, stanje i perspective. Zagreb: Informator, 1987.

Korać, Dušan. Spomenici i spomen ploče u čast učesnika i događaja NOB na području Zagreba. Zagreb: Muzej grada Zagreba, 1958a.

Korać, Dušan. "Otkrivanje spomen-ploče palim muzejsko-konzervatorskim radnicima i proslava 13-godišnjice oslobođenja Zagreba u Muzeju grada Zagreba”. Vijesti Društva muzejsko-konzervatorskih radnika NR Hrvatske 3 (1958b): 65-66.

Лајбеншпергер, Ненад. „Меморијали Другог светског рата у служби дневно-политичких потреба социјалистичке Југославије“. У Простори памћења, том 1, Архитектура, Spaces of Memory, Architecture, edited by Aleksandar Kadijević and Milan Popadić, 283-297. Београд: Филозофски факултет, Одељење за историју уметности, 2013.

Manojlović Pintar, Olga. Arheologija sećanja. Spomenici i identiteti u Srbiji 1918-1989. Beograd: Udruženje za društvenu istoriju, Čigoja štampa, 2014.

Mikuž, Stane. Spomenik narodnoosvododilne borbe. Celje: Općinski odbor zveze Borcev NOV Celje, 1959.

Mitić, Svetolik. Spomen-park Kumrovec. Kumrovec i Beograd: Spomen park Kumrovec i NIŠRO Turistička štampa, 1979 .

Mitić, Svetolik. Memorial park Kumrovec. Kumrovec i Beograd: Spomen park Kumrovec i NIŠRO Turistička štampa, 1982.

Поповски, Јован. Илинденското востание Крушево. Белград: Туристичка штампа, 1983.

Radojković, Miroljub i Mirko Miletić. Komuniciranje, mediji i društvo. Zrenjanin: Stylos, 2005.

Simonović, Rodoljub i Boro Miljanović. Šekovići. Središte partizanskog Birča. Šekovići i Beograd: Narodni univerzitet „Stanko Menjić” i NIŠRO Turistička štampa, 1984.

Sjećanja u kamen uklesana. Spomenici radničkog pokreta i narodne revolucije u Hrvatskoj. Zagreb: Ured za informacije Izvršnog vijeća Sabora Narodne republike Hrvatske, 1960. 
Spomen knjiga posvećena proslavi otkrivanja spomenika palim borcima u Kupirovu 27 jula 1957 godine. Beograd: n.p, 1958.

Stamenković, Đorđe. Bubanj Memorial park, The Red Cross concentration camp, Niš. Niš and Belgrade: Tourist Union i NIŠRO Turistička štampa, 1982.

Stamenković, Đorđe. Spomen-park Bubanj, Logor Crveni krst, Niš. Niš i Beograd: Turistički savez Opštine Niš i NIŠRO ,Turistička štampa”, 1981.

Stanimirović, Angelina i Milivoje Marinković. Spomenik Kadinjača Titovo Užice. Titovo Užice i Beograd: RO Muzej, Narodni muzej - OOUR Spomenik Kadinjača i NIŠRO “Turistička štampa”, 1984. ${ }^{2}$

Stanković, Stevan, M. Turizam u Jugoslaviji. Beograd: Turistička štampa, $1990 .{ }^{3}$

Стошић, Адам. Крушевац и околина, културно историјски споменици. Крушевац: Друштво љубитеља старина и уметности, 1978.

Rakita, Milan. Prostorno-političke i memorijalne infrastructure socijalističke Jugoslavije. Beograd: Rosa Luxemburg Stiftung Southeast Europe, 2019.

Trivunčić, Radovan. Spomen područje Jasenovac. Zagreb: Turistkomerc, Spomen područje Jasenovac, 1975.

Urlić, Velimir i Jakša Gareljić. Spomen područje Biokovo, Makarska. Makarska i Beograd: Centar za kulturu općine Makarska i NIŠRO Turistička štampa, 1983.

Vukotić, Manjo. Memorijalni prostor Boško Buha Jabuka. Beograd: NIŠRO „Turistička štampa”, 1979.

\section{UNPUBLISHED SOURCES}

Archive of Yugoslavia, Belgrade (AY) - 297 (Savez Udruženja boraca narodno oslobodilačkog rada Jugoslavije) II -323 .

\section{INTERNET SOURCES}

Jan Kempenaers - http://www.jankempenaers.info/ (accessed 26.06.2020).

\section{POPULARIZACIJA SPOMENIKA POSVEĆENIH DRUGOM SVETSKOM RATU U JUGOSLAVIJI KROZ ŠTAMPANE MEDIJE: KNJIGE, TURISTIČKI VODIČI I ALBUM ZA SLIČICE}

Publikacije o podignutim spomenicima borcima i civilima stradalim tokom Drugog svetskog rata u Jugoslaviji počele su da se pojavljuju krajem pedesetih godina 20. veka. One su bile posvećene jednom spomeniku ili spomen obeležjima podignutim na nekom prostoru. Tokom šezdesetih izašao je ograničen broj izdanja, od kog je najznačajniji bio album fotografija „Jugoslavija. Spomenici revoluciji“, koji je izdao SUBNOR Jugoslavije. Podaci o memorijalnim obeležjima su vremenom počeli da se nalaze i u turističkim vodičima. Prvo su to bile kraće informacije, a vremenom je broj podataka o memorijalima, kao objektima ili prostorima koje vredi posetiti, rastao. Tokom druge polovine sedamdesetih pojavili su se i specijalni turistički vodiči posvećeni samo jednom memorijalu ili memorijalnom kompleksu. Tu se posebno istakla Biblioteka Spomenici revolucije koju je izdavala beogradska Turistička štampa. Popularnost koju su spomenici imali u društvu dovela je i do štampanja posebnog albuma za sličice sa motivima spomenika. Namera štampanja ovakvih publikacija je bila popularizacija spomenika, odnosno informisanje stanovništva Jugoslavije o podignutim spomenicima. Međutim, postojala je i ideološka strana toga. Kroz knjige o spomenicima država i komunistička partija su želele da dodatno podvuku jugoslovenske ratne napore $i$ date žrtve u pobedi protiv fašizma. Publikacije su korišćene u vaspitavanju dece $i$ omladine, diplomatskim odnosima $i$ uopšte u celokupnoj državnoj propagandi o ulozi jugoslovenskih partizana, pod vođstvom komunističke partije Jugoslavije, u pobedi nad fašizmom.

Ključne reči: spomenici, memorijali, publikacije, knjige, turistički vodiči, album za sličice, Narodnooslobodilački rat u Jugoslaviji. 